\title{
Public Health Information Retrieval from Non-health Databases
}

Thumeka Mgwigwi

Reference and Liaison Librarian

York University

thumekam@yorku.ca

\begin{abstract}
This study examines the extent to which non-health databases index public health and health care related journals. The field of public health and health care is unique and multidisciplinary and therefore presents some challenges for researchers looking for published literature in the field. These challenges compel researchers to look beyond databases such as Medline and search a wide array of databases in various fields. A list of journal titles from non-health databases in various fields was used to compare title coverage in Ovid Medline to other databases. The databases used in this study were Canadian Business \& Current Affairs (CBCA) Complete which is a multidisciplinary database; $\mathrm{ABI} /$ Inform covering business literature; Public Affairs Information Services (PAIS); EconLit; Psyclnfo focusing only on public health journals and eliminating psychology specific journals; Sociological Abstracts; and Women's Studies International.
\end{abstract}

\section{Keywords}

public health; health care; information retrieval; health databases

\section{Introduction}

The field of public health and health care is a unique and multidisciplinary field that presents some challenges for researchers looking for published literature. Some researchers and health care professionals may rely on Medline and Cumulated Index to Nursing and Allied Health Literature (CINAHL) for their research, not appreciating other potentially useful databases that index public health and health care related journals. The public health and health care field draws literature from other disciplines such as administration, law, public policy, business, economics, etc. The nature of public health information also poses a challenge to librarians who must be experts at searching databases outside their areas of expertise.

To maximise the effectiveness of health care research, health professionals need to go beyond the obvious databases and search databases that are associated with other fields. Choosing the right database is imperative for finding relevant information based on the research topic at hand. Numerous researchers have tackled this topic; however, much of the research has focused on journal coverage rather than databases that index those journals. 
This study is Phase 1 of an ongoing research project and seeks to identify non-health databases that index health-related journals in comparison to Ovid Medline (1946 to present). The assumption of the study is that there are other databases that index public health literature. As the health care field draws literature from various fields, a sample of eight databases covering various disciplines was chosen for this study. These databases are Canadian Business \& Current Affairs (CBCA) Complete which is a multidisciplinary database; $\mathrm{ABI} /$ Inform covering business literature; Public Affairs Information Services (PAIS); EconLit; Psyclnfo with a focus on public health journals and eliminating any psychology related journals; Sociological Abstracts; and Women's Studies international.

\section{Description of Databases Studied}

\section{Ovid Medline (1946-present)}

Medline is the most commonly used database for medical and health information. It indexes approximately 4,000 biomedical journals covering medicine, nursing, dentistry, veterinary science and preclinical sciences. Medline has bibliographic citations and author abstracts from more than 5,400 biomedical journals published in the United States and 70 other countries. The database contains over 13 million citations dating back to1946, including more than 130,000 population-related journal citations. Although coverage is worldwide, most records are derived from English-language sources or have English abstracts.

\section{Canadian Business \& Current Affairs (CBCA) Complete}

Canadian Business \& Current Affairs (CBCA) Complete is Canada's largest and most comprehensive bibliographic full-text reference and current events database. It is available through the ProQuest interface, with full text content from all four CBCA database subsets (Business, Current Events, Education and Reference). Subject coverage is comprehensive, and information is available from a broad range of Canadian sources. With over 4.5 million records and more than 1,680 titles, this database is ideal for anyone interested in current events, business, science, the arts and academic information produced in Canada. CBCA Complete provides high-quality indexing of nearly 600 periodicals and daily news sources.

\section{ABI Inform}

$A B I$ Inform incorporates management, industry and company specific information which is both practical and theoretical in nature. Subjects covered include: finance, public administration, marketing, management, economics, taxation, telecommunications, corporate strategies, competitive and product information. It contains citations and abstracts for over 1,000 business and management publications. More than 600 of these titles are available in full-text. $\mathrm{ABI} / \mathrm{Inform}$ has a variety of content as it combines the foremost business journals and the leading sources of online business news with international and scholarly content. 


\section{Women's Studies International}

Women's Studies International covers topics from the core disciplines in Women's Studies to the latest scholarship in feminist research. Coverage includes more than 871,000 records from 1972 and earlier to the present. This database supports curriculum development in the areas of sociology, history, political science and economy, public policy, international relations, arts and humanities, business and education. Nearly 800 essential sources include: journals, newspapers, newsletters, bulletins, books, book chapters, proceedings, reports, theses, dissertations, NGO studies, web sites, web documents and grey literature. Over 2,000 periodical sources are represented.

\section{EconLit}

EconLit prides itself as the "world's foremost source of references to economic literature." It serves as a good source of citations and abstracts to economic research dating back to 1969. It provides full-text articles in all fields of economics, including capital markets, country studies, econometrics, economic forecasting, environmental economics, government regulations, labor economics, monetary theory, urban economics and much more. Types of records indexed in EconLit include journal articles, books, collective volume articles, dissertations, working papers and full-text book reviews. These sources bring the total number of records available in the database to over a million.

\section{Psyclnfo}

Psyclnfo provides abstracts and citations to scholarly literature in the psychological, social, behavioural and health sciences. The database includes material of relevance to psychologists and professionals in related fields such as psychiatry, management, business, education, social science, neuroscience, law, medicine and social work. Updated weekly, Psyclnfo provides access to journal articles, books, chapters and dissertations.

\section{Public Affairs Information Services (PAIS)}

The PAIS International database indexes international literature in public affairs, public and social policies, and international relations. The database contains references to more than 556,400 journal articles, books, government documents, statistical directories, grey literature, research reports, conference reports, publications of international agencies, microfiche, Internet material, and more. In addition to English, some of the indexed materials are published in French, German, Italian, Portuguese and Spanish and come from over 120 countries around the world. 


\section{Sociological Abstracts}

Sociological Abstracts indexes international literature in sociology and other related disciplines in the social and behavioural sciences. There are nearly 2,000 serial publications from a variety of sources including journal articles, conference papers, books and dissertations, plus citations to important book reviews related to the social sciences. Adding to the scope and breadth of this resource is a back file that begins in 1952 with records published by the then print version of Sociological Abstracts. Sociological abstracts also offers a global perspective in sociology with $40 \%$ of the provided content published outside North America.

\section{Literature Review}

Although there have been very few studies that identify non-health databases that index public health and health care literature, one article by Greyson looked at how one can enhance search results by searching beyond Medline. The study specifically looked at non-biomedical sources for systematic reviews of pharmaceutical policy. Some nonbiomedical databases included in his study were ABI/Inform, EconLit, Web of Science, Public Affairs Information Service (PAIS) and Proquest Digital Dissertations and Theses. The article concluded that depending solely on Medline and Embase for research may be inadequate, and researchers should "consider including nonbiomedical databases, particularly economic and interdisciplinary databases in their search strategies" (Greyson, 2010).

Another article by Alpi (2005) explored expert searching in public health by looking at the characteristics of public health information needs and how those needs can be satisfied by using various resources. The article mentioned that some journals that have articles relevant to public health are not indexed in Medline. This supports the aim of this study which was to identify relevant public health journals not indexed in Medline, but indexed in other databases.

Pickett's article "Reaching beyond Medline: a beginner's overview of electronic biomedical resources," looked at biomedical sources other than Medline. Pickett rightfully stated that "users in the biomedical field may believe that if they can't find what they are looking for in Medline, the information must not exist. This is simply not the case. Many casual users of these systems may be surprised to learn that Medline is, in fact, quite limited in scope and content."

To further indicate that Medline should not be the sole database to search for public health information, Aalai, et al. conducted a study looking at the unique content of the Global Health Database, comparing it to Medline. The authors used controlled vocabulary for both databases, and the results of the study indicated that Medline's content is more focused on North American and European publications, whereas Global Health Database is more universal. Some interesting key points from the article are that librarians in public health need good access to high-quality information from a wide variety of sources, that public health information is not adequately covered in databases such as Medline, and that information seeking must be expanded to other sources. 
There have been numerous other studies that compare various health databases and their coverage of health journals. A major study conducted in 1997 by the Task Force on Bibliographic Access for the Allied Health Literature - which was created by the Nursing and Allied Health Resources Section of the Medical Library Association (MLA) - sought to identify core journals of various allied health fields and assess the coverage given these titles by the major indexing and abstracting services. However, coverage of these titles focused on health-related databases such as Medline, EMBASE, Psyclnfo and CINAHL. One of the articles that resulted from this study was, "Mapping the literature of public health and community nursing" whose purpose was to "identify the journals most cited in public health and community nursing and to determine which databases provide the most thorough indexing access to these journals" (Alpi and Adams, 2007).

\section{Methodology}

To identify health journals indexed in non-health databases, a list of journal titles was obtained from each non-health database. For databases available through ProQuest, a list of titles was obtained by using the 'Look up Publications' feature. Using this feature, all titles that had the term 'health' were identified and selected. For other databases, the vendor's website was used.

To determine the number of articles indexed in each of the databases, each database was searched using the title of the journal. The search was limited to the Publication field of the database, and this option was supported by all the databases used in this study. To make a comparison, the same titles were searched to determine their coverage in Ovid Medline. It quickly became apparent that searching Ovid Medline using the Journal Name field retrieved inaccurate results for some titles. For example, a search for the Canadian Journal of Public Health using the Journal Name field retrieved zero results, but searching by the International Standard Serial Number (ISSN) retrieved more than 5,000 results. For this reason Ovid Medline was searched using the journal's ISSN. In cases where a search retrieved zero results in Medline, different options were explored. This included searching both the ISSN and Journal Name fields.

Titles included in the results section of this study were those that had a higher number of articles indexed in a non-health database than in Ovid Medline. All the journals had to be scholarly, current and have at least 100 indexed articles to be included in this study. For Psyclnfo, all the psychology specific titles, such as those related to mental health or psychiatry, were excluded. After all the databases were searched, a total of 74 journals were identified, only 11 of which had fewer than 100 articles indexed in any given database.

There are, however, some limitations to this methodology as only journals with the name 'health' in the title were studied. Although the public health field is interdisciplinary, this study has not covered all possible non-health databases that could be useful for health research. Another limitation is the fact that the study focused only on journal title coverage and not the articles, as most of the studies have done. As 
such, Phase 2 of this ongoing study will look beyond health related journals and study non-health related journals that index health literature.

\section{Discussion}

As mentioned earlier, there were some inconsistencies when searching Ovid Medline. For instance, when searching certain titles, such as the Canadian Journal of Public Health, using the journal's title and limiting the search to Journal Name produces different results compared to using the ISSN.

The results of the study, though, seem to indicate that subject specific databases can sometimes have a higher number of health related journals when compared to Ovid Medline. For example, Table 1 shows that compared to Ovid Medline, Women's Studies International indexes more articles from the Journal of Women's Health which is one of the major journals covering women's health issues. Another journal of note in Table 1 is National Women's Health Report which has almost no coverage in Medline but has about 962 articles in Women's Studies International.

Table 1: Women's Studies International

\begin{tabular}{|l|l|l|}
\hline Journal Title & $\begin{array}{l}\text { Women's Studies } \\
\text { International }\end{array}$ & Medline \\
\hline Journal of Women's Health & 6807 & 2204 \\
\hline Women and Health & 2970 & 1174 \\
\hline Health Care for Women International & 2241 & 1422 \\
\hline Women's Health Issues & 1460 & 816 \\
\hline Reproductive Health Matters & 1918 & 365 \\
\hline $\begin{array}{l}\text { Journal of Midwifery \& Women's } \\
\text { Health }\end{array}$ & 1755 & 1055 \\
\hline $\begin{array}{l}\text { Journal of Women's Health \& Gender- } \\
\text { Based Medicine }\end{array}$ & 1048 & 461 \\
\hline National Women's Health Report & 962 & 2 \\
\hline Archives of Women's Mental Health & 914 & 248 \\
\hline $\begin{array}{l}\text { Perspectives on Sexual \& } \\
\text { Reproductive Health }\end{array}$ & 649 & 317 \\
\hline $\begin{array}{l}\text { International Perspectives on Sexual \& } \\
\text { Reproductive Health }\end{array}$ & 130 & 54 \\
\hline
\end{tabular}

$\mathrm{ABI}$ Inform is another database that seems to fare better with indexing as indicated in Table 2. Titles of note are Health Affairs, Health Care Financing Review, International Journal of Health Care Quality Assurance, European Journal of Public Health, and Marketing Health Services. 
Table 2: ABI Inform

\begin{tabular}{|l|l|l|}
\hline Journal Title & ABI Inform & Medline \\
\hline Health Affairs & 6004 & 5131 \\
\hline Health Care Financing Review & 2803 & 1251 \\
\hline $\begin{array}{l}\text { Australian and NZ Journal of Public } \\
\text { Health }\end{array}$ & 2122 & 1773 \\
\hline Health Services Research & 2211 & 2111 \\
\hline $\begin{array}{l}\text { Int. Journal of Health Care Quality } \\
\text { Assurance }\end{array}$ & 1866 & 616 \\
\hline $\begin{array}{l}\text { Journal of Health Politics, Policy and } \\
\text { Law }\end{array}$ & 1467 & 1401 \\
\hline European Journal of Public Health & 1916 & 771 \\
\hline Marketing Health Services & 1829 & 537 \\
\hline Health Care Management Review & 1675 & 1203 \\
\hline Journal of Health Economics & 1277 & 1177 \\
\hline $\begin{array}{l}\text { Frontiers of Health Services } \\
\text { Management }\end{array}$ & 896 & 468 \\
\hline $\begin{array}{l}\text { The Journal of Behavioral Health } \\
\text { Services \& Research }\end{array}$ & 846 & 380 \\
\hline $\begin{array}{l}\text { Journal of Immigrant and Minority } \\
\text { Health }\end{array}$ & 682 & 162 \\
\hline Quality Management in Health Care & 570 & 572 \\
\hline $\begin{array}{l}\text { The European Journal of Health } \\
\text { Economics }\end{array}$ & 551 & 317 \\
\hline Health Economics Policy and Law & 230 & 194 \\
\hline $\begin{array}{l}\text { International Journal of Health Care } \\
\text { Finance and Economics }\end{array}$ & 192 & 132 \\
\hline & & \\
\hline
\end{tabular}

There are some titles that are indexed in multiple databases that Ovid Medline does not index. Although Psyclnfo can be considered a health related database, it was included in this study to determine whether it indexed general health related journals. Of note is the Health Education journal as shown in Table 3, which is not indexed in Medline but has about 508 articles in Psyclnfo. It should be noted that Ovid Medline does index another journal by the same name; however, the Health Education journal in Medline is published by the American Alliance for Health in the United States, whereas the one indexed in Psyclnfo is published by Emerald Group Publishing in the United Kingdom. There are other health titles that are listed in Psyclnfo but are not available in Ovid Medline, including Home Health Care Management \& Practice and Health Sociology Review. 
Table 3: Psyclnfo

\begin{tabular}{|l|l|l|}
\hline Journal Title & Psyclnfo & Medline \\
\hline Journal of Adolescent Health & 2761 & 1663 \\
\hline Health Education Research & 1416 & 1029 \\
\hline Family and Community Health & 827 & 501 \\
\hline Health Communication & 751 & 566 \\
\hline $\begin{array}{l}\text { Journal of Immigrant and Minority } \\
\text { Health }\end{array}$ & 256 & 162 \\
\hline Journal of Aging and Health & 628 & 609 \\
\hline Health Education & 508 & 0 \\
\hline $\begin{array}{l}\text { International Quarterly of } \\
\text { Community Health Education }\end{array}$ & 479 & 191 \\
\hline Health Promotion International & 452 & 317 \\
\hline $\begin{array}{l}\text { Home Health Care Management \& } \\
\text { Practice }\end{array}$ & 502 & 0 \\
\hline Health Expectations & 259 & 158 \\
\hline Health, Risk \& Society & 278 & 2 \\
\hline Health Sociology Review & 190 & 0 \\
\hline $\begin{array}{l}\text { Primary Health Care Research and } \\
\text { Development }\end{array}$ & 198 & 19 \\
\hline Social Theory and Health & 137 & 0 \\
\hline $\begin{array}{l}\text { International Journal of Child and } \\
\text { Adolescent Health }\end{array}$ & 116 & 0 \\
\hline
\end{tabular}

Although CBCA Complete is a multidisciplinary database, it did not seem to exceed Ovid Medline in its indexing of health and health care related journals, except for a couple of journals that are Canadian specific. This is not surprising (see Table 4).

Table 4: CBCA Complete

\begin{tabular}{|l|l|l|}
\hline Journal Title & CBCA Complete & Medline \\
\hline Health Care & 715 & 494 \\
\hline Canada's Mental Health & 387 & 197 \\
\hline $\begin{array}{l}\text { Canadian Journal of Women's } \\
\text { Health Care }\end{array}$ & 387 & 0 \\
\hline $\begin{array}{l}\text { Canadian Journal of Community } \\
\text { Mental Health }\end{array}$ & 206 & 0 \\
\hline Health Policy Forum & 194 & 0 \\
\hline
\end{tabular}

Neither Sociological Abstracts (Table 5) nor EconLit (Table 6) had a significant list of health titles compared to Medline. It is worth noting that Sociological Abstracts seemed to fare better when it came to indexing the Sociology of Health and Illness journal. This is one of the most important journals covering different aspects of health and illness in a sociological context. Another journal of interest is Home Health Care Management \& Practice which Medline does not index. This journal also has a significant number of articles in Psyclnfo (see Table 3 above). 
Table 5: Sociological Abstracts

\begin{tabular}{|l|l|l|}
\hline Journal Title & Sociological Abstracts & Medline \\
\hline Sociology of Health and Illness & 2799 & 578 \\
\hline $\begin{array}{l}\text { Journal of Health and Social } \\
\text { Behavior }\end{array}$ & 1461 & 1415 \\
\hline Health Education Journal & 734 & 101 \\
\hline $\begin{array}{l}\text { Home Health Care Management \& } \\
\text { Practice }\end{array}$ & 476 & 0 \\
\hline Health & 320 & 155 \\
\hline Critical Public Health & 267 & 1 \\
\hline Health, Risk \& Society & 255 & 2 \\
\hline Health Sociology Review & 224 & 0 \\
\hline Social Theory and Health & 171 & 0 \\
\hline
\end{tabular}

Table 6: EconLit

\begin{tabular}{|l|l|l|}
\hline Journal Title & EconLit & Medline \\
\hline Health Economics & 1357 & 1170 \\
\hline Journal of Health Economics & 1381 & 1177 \\
\hline Health Care Management Science & 492 & 416 \\
\hline $\begin{array}{l}\text { The European Journal of Health } \\
\text { Economics }\end{array}$ & 503 & 317 \\
\hline $\begin{array}{l}\text { Applied Health Economics and } \\
\text { Health Policy }\end{array}$ & 270 & 177 \\
\hline $\begin{array}{l}\text { International Journal of Health Care } \\
\text { Finance and Economics }\end{array}$ & 233 & 132 \\
\hline
\end{tabular}

According to the results of a study conducted by Greyson, PAIS did not have any significant citations that could have been included in his study. This study also found a similar pattern as there was only one journal of note, Health Education and Behavior, which had slightly more articles when compared to Medline. This was an interesting finding as the author was hoping to uncover some health policy related journals from PAIS. As some researchers tend to rely on specific journals for research, it might be useful to search a subject specific database to access articles in those journals rather than relying solely on Medline.

\section{Conclusion}

Although Medline still offers major coverage of public health journals, there are nonhealth databases that should not be overlooked, as Medline tends to focus more on clinical and biomedical literature. The results of this study seem to support the idea that researchers need to choose their databases based on the nature of the topic at hand. For instance, a researcher who is writing a paper on a women's health issue may want to search the literature indexed in women's studies databases. The next step of this study will explore databases in other fields, such as education, and will examine health related articles indexed in non-health databases regardless of the journal indexing the articles under study. 


\section{Works Cited}

Aalai, Elham, et al. "Accessing Public Health Information: A Preliminary Comparison of CABI's Global Health Database and Medline." Health Information and Libraries Journal. 26.1 (2009): 56-62. Print.

ABI Inform. Web. 30 Jul. 2011. <http://www.proquest.com/enUS/catalogs/databases/detail/abi inform complete.shtml>.

Alpi, Kristine, and Mary Adams. "Mapping the Literature of Public Health and Community Nursing." Journal of the Medical Library Association. 95.1 (2007): E6, E6-E9. Print.

Alpi, Kristine. "Expert Searching in Public Health." Journal of the Medical Library Association. 93.1 (2005): 97, 97-103. Print.

Arnold, Susan, Virginia Bender, and Sally Brown. "A Review and Comparison of Psychology-Related Electronic Resources." Journal of Electronic Resources in Medical Libraries. 3.3 (2006): 61, 61-80. Print.

Canadian Business and Current Affairs (CBCA) Complete. Web. 20 May 2011. <http://www.proquest.com/en-US/catalogs/databases/detail/cbca.shtml>.

EconLit. Web. 15 Nov. 2011. <http://www.aeaweb.org/econlit/index.phps.

Greyson, Devon. "Non-Biomedical Sources for Systematic Reviews of Pharmaceutical Policy." Journal of the Medical Library Association. 98.1 (2010): 85-87. Print.

Medline (Ovid). Web 15 Nov. 2011. <http://www.ovid.com/site/catalog/DataBase/901.jsp>.

Pickett, Keith M. "Reaching Beyond MEDLINE: A Beginner's Overview of Electronic Biomedical Resources." Journal of Hospital Librarianship. 8.4 (2008): 398-410. Print.

Psyclnfo. Web. 21 Nov. 2011. <http://www.apa.org/pubs/databases/psycinfo/index.aspx>.

Public Affaires Information Services (PAIS) Web. 2 Dec. 2011. $<$ http://www.csa.com/factsheets/pais-set-c.php>.

Sociological Abstracts (ProQuest) Web. 2 Dec. $2011<$ http://www.proquest.com/enUS/catalogs/databases/detail/socioabs-set-c.shtml>.

Women's Studies International. Web. 28 Nov. 2011 $<$ http://www.ebscohost.com/academic/womens-studies-international $>$. 